\title{
The Effect of Phosphorous Fertilization on Indian Pennyworth (Centella asiatica L. Urban) in High Altitude
}

\author{
Sandra Arifin Aziz ${ }^{1^{*}}$, Munif Ghulamahdi ${ }^{1)}$ and Andria Afrida ${ }^{2)}$ \\ Received 11 October 2010/Accepted 24 February 2011
}

\begin{abstract}
The experiment was conducted to determine the effect of phosphorous fertilization on growth and production of Indian pennyworth (Centella asiatica $\mathrm{L}$. Urban) in the high altitude (1,500 $\mathrm{m}$ above sea level/asl). This experiment was carried out at Gunung Putri experimental station Balittro, Cipanas, Cianjur in October 2008 until April 2009. The treatment was laid-out in a Complete Randomized Block Design and consisted of single factor with 5 replications. The factor was $\mathrm{P}_{2} \mathrm{O}_{5}$ fertilization i.e. 0, 30, 60, 90, and $120 \mathrm{~kg} \mathrm{P}_{2} \mathrm{O}_{5}$ ha $\mathrm{a}^{-1}$. The results of the experiment showed that $\mathrm{P}_{2} \mathrm{O}_{5}$ fertilizer significantly increased the total leaf number, leaf length, the total flower number, leaf thickness of mother plant and production components at 6 month after planting. The highest production (1.34 ton dry weight.ha ${ }^{-1}$ ) was achieved by $60 \mathrm{~kg} \mathrm{P}_{2} \mathrm{O}_{5} \mathrm{ha}^{-1}$. The optimum dosage to improve dry weight production of Indian pennyworth in high altitude was $65.84 \mathrm{~kg} \mathrm{P}_{2} \mathrm{O}_{5} \mathrm{ha}^{-1}$.
\end{abstract}

Key words: Centella asiatica L., phosphorous fertilization, production

\section{INTRODUCTION}

The data from one of the medicinal company in Indonesia showed the need of a supply of approximately 100 tons Indian pennyworth.year ${ }^{-1}$. Indian pennyworth is the raw material for at least ten types of herbal medicine on the market, with simplicia content in the packaging between $15-25 \%$ (Januwati and Yusron, 2005). The bioactive compounds in Indian pennyworth include asiaticoside, thankunside, isothankunside, madecassoside, brahmaside, brahmic acid, modasiatic acid, meso-inosetol, centellose, carotenoids, $\mathrm{K}, \mathrm{Na}, \mathrm{Ca}, \mathrm{Fe}$, vellarine, tannin, mucilago, resin, pectin, sugar, protein, phosphorous, and vitamin B. In addition, Indian pennyworth contains little vitamin $\mathrm{C}$ and some essential oils (Winarto and Surbakti, 2003).

Standardized cultivation techniques research is needed to increase the quality of the plant product. One of important factor in plant production includes phosphorous availability in the soil. Nutrient availability is generally low in phosphorous in soil like Andisols. Andisols at the research location (Experimental research station at Gunung Putri Cipanas) has a very low soil $\mathrm{pH}$, medium C-organic, low $\mathrm{P}$ nutrient (1.22 ppm), and high micro-nutrient elements (Sutardi, 2008). Andisols has andic or high phosphorous retention so that most of the phosphorous was bound by the elements $\mathrm{Fe}$ and $\mathrm{Al}$ (Hardjowigeno, 2003). Whereas Bermawie et al.
(2008) stated that asiaticoside production in the highland is higher than in the lowland.

The function of phosphorous as a constituent of macromolecular structure is prominent in nucleic acids, in energy transfer (ADP and ATP), and as biochemical reaction regulator that can activate protein in signal transduction (Marschner, 1995). Moreover phosphorous is active in asiaticoside biosynthesis as Isopentenil Pirophosphate/IPP and Dimetyl Pirophosphate/DMAP in mevalonate pathway and as Deoxixylolose Phosphate/DXP in non-mevalonate pathway (Agusta, 2006).

The objective of this research was to determine the optimum dosage of phosphorous fertilization on Indian pennyworth growth and production on high altitude.

\section{MATERIALS AND METHODS}

This experiment was carried out at Gunung Putri experimental station, Balittro, Cipanas, Cianjur district, on Andisols soil $1500 \mathrm{~m}$ asl from October 2008 until April 2009. The treatment was arranged in a Complete Randomized Block Design and consisted of single factor with 5 replications, with 5 plots for each replication, so that the total experimental unit was 25. The factor was $\mathrm{P}_{2} \mathrm{O}_{5}$ fertilization from the dosages $0,30,60,90$, and 120 $\mathrm{kg} \mathrm{P}_{2} \mathrm{O}_{5} \mathrm{ha}^{-1}$. The plant used was Boyolali accession, as one of the accession with the highest asiaticoside

\footnotetext{
${ }^{1}$ Lecturer of Department Agronomy and Horticulture, Faculty of Agriculture, Bogor Agricultural University J1. Meranti Kampus IPB Darmaga, Bogor 16680 Telp/Fax (0251) 8629353, Email: sandraaziz@yahoo.com (*Corresponding Author)

${ }^{2}$ Alumnus of Department Agronomy and Horticulture
} 
productivity in Gunung Putri Experimental station (Martono et al., 2010).

Observation was conducted on growth and production components. Replanting was done in 2 WAP. Manual weeding was done every two weeks. Growth was observed starting 2 weeks after planting (WAP) and every 2 weeks thereafter on 6 uniform mother plants in each plot. Observations on growth included total leaf of mother plant, petiole length, leaf length, leaf width, number of primary vine, length of primary vine, number of internodes (2-16 WAP), leaf thickness, petiole diameter (2-12 WAP), total flowers of mother plant (6-16 WAP), and number of secondary vine (8-16 WAP). Observations of production included analysis of phosphorous content of leaf tissue harvested at 5 months after planting (MAP), shoot fresh and dry weight harvested at 5 and $6 \mathrm{MAP}$, and moisture content of harvested materials.

The influence of $\mathrm{P}$ fertilization was determined by $\mathrm{F}$ test at $95 \%$ level of confidence. The significant effect on the observed variables was analyzed further using Duncan Multiple Range Test (DMRT) at 95\% level of confidence. Orthogonal polynomial test determined the response curve of variable relationships. Optimum dosage of phosphorous fertilizer was determined by regression analysis.

\section{RESULTS AND DISCUSSION}

\section{General Condition of the Experiment}

Based of primary data from experiment at Gunung Putri experimental station Balittro,Cipanas, air temperature average during experiment ranged from $15.78-23.75^{\circ} \mathrm{C}$ with maximum temperature in March, even though the minimum temperature occurs in February. Rainfall during experiment ranged from $721.5-1602 \mathrm{~mm} / \mathrm{month}$ and the number of rainy days ranged from 13-18 days. The highest rainfall occurs in February, but the lowest rainfall occurs in March. The results of soil analysis at the beginning of the experiment showed that soil in the experiment sites have low soil pH (5.11), medium C-organic content (2.46\%), medium $\mathrm{N}$-total $(0.22 \%)$, medium $\mathrm{C} / \mathrm{N}$ ratio (11.18\%), medium $\mathrm{P}$-available (20.32 ppm), medium K (0.3 me/100 g), medium Ca (7.34 me/100g), very high Fe (16 100 ppm), very high Mn (164.26 ppm), $12.63 \mathrm{me} / 100 \mathrm{~g} \mathrm{CEC}$, and $38.46 \%$ base saturation.

Field growth percentage is $99.12 \%$. Weeds found in the fields were Axonopus compressus, Borreria alata, Artemisia annua. During the experiment, there were no significant pests and diseases incidence, some of the pests were caterpillars, snails, grasshoppers (Valanga mausiena) and naked snails (Vaginula bleekeri). The low temperature during experiment (in January and February) caused crop freezing injury, i.e. necrosis dark brown lesions on the leaves.

The result of orthogonal polynomial test (Table 1) used to determine the response curve of variable relationships showed a cubic response for total leaf number at $4 \mathrm{WAP}$, leaf length at $4 \mathrm{WAP}$ and total flower number at $16 \mathrm{WAP}$, and quartic response for leaf thickness at $8 \mathrm{WAP}$, only total flower number at 6 WAP showed a quadratical response. This condition showed that other factors may be influencing the test result

Table1. Orthogonal polynomial test on growth components of Indian Pennyworth

\begin{tabular}{lcccc}
\hline \multirow{2}{*}{ Variables } & \multicolumn{3}{c}{ Pr > F } \\
\cline { 2 - 5 } & Linear & Quadratic & Cubic & Quartic \\
\hline Total lef number at 4 WAP & 0.5207 & 0.4540 & $0.0041^{* *}$ & 0.0596 \\
Leaf length at 4 WAP & 0.6481 & 0.3136 & $0.0297^{* *}$ & 0.0831 \\
Total flower number at 6 WAP & 0.3192 & $0.0411^{*}$ & 0.2479 & 0.1248 \\
Total flower number at 16 WAP & 0.6497 & 0.0357 & $0.0218^{* *}$ & 0.9108 \\
Leaf thickness at 8 WAP & 0.1342 & 0.1697 & 0.0230 & $0.0143^{*}$ \\
\hline
\end{tabular}

Note: **: very significant on the level of $1 \%$, *: significant on the level $5 \%$ 


\section{Plant Growth}

Phosphorous fertilization had significant impact on the total leaf number and leaf length at 4 WAP, the total flowers at 6 and 16 WAP, and the leaf thickness at 8 WAP. Treatment of $30 \mathrm{~kg} \mathrm{P}_{2} \mathrm{O}_{5}$ $\mathrm{ha}^{-1}$ had a significantly highest total leaf number, leaf length and leaf thickness $(35.31,12.46$, and $28.13 \%$, respectively) compared to treatment of $60 \mathrm{~kg} \mathrm{P}_{2} \mathrm{O}_{5}$ $\mathrm{ha}^{-1}$. Treatment of $60 \mathrm{P}_{2} \mathrm{O}_{5} \mathrm{ha}^{-1}$ increased the total flowers of mother plant $54.88 \%$ compared to that of $90 \mathrm{P}_{2} \mathrm{O}_{5} \mathrm{ha}^{-1}$ (Table 2). Phosphorous fertilization insignificantly influenced petiole length, leaf width, petiole diameter, number of primary vine, primary vine of length, number of internodes, and number of secondary vine in all observations.

Phosphorous fertilization significantly influenced total leaf number and leaf length at 4 WAP, the total flower number of mother plant at 6 and 16 WAP, and the leaf thickness at 8 WAP. Sutardi (2008) stated that phosphorous fertilization insignificantly influenced in all growth variables of Indian pennyworth, except the SPAD chlorophyll meter value on the old leaves.

The treatment of $30 \mathrm{~kg} \mathrm{P}_{2} \mathrm{O}_{5} \mathrm{ha}^{-1}$ showed response of total leaf number was better than the other treatments. Phosphorous was an element that serves as a constituent metabolites and complex compounds, activators, cofactors, and plays a role in the development of hair roots (Marschner, 1995). Root growth was stimulated by a number of nutrients that can be absorbed by plants and used for metabolic processes. Sufficient nutrients supported growth of plant organs, including the total leaves of mother plant.

Phosphorous fertilization did not influence petiole length, leaf width, petiole diameter, number of primary vine, primary vine of length, number of internodes, number of secondary vine, phosphorous content of plant tissue, as well as total of shoot fresh and dry weight harvested at 5 MAP. The expected absorption of phosphorous by plant is not optimal. Soil analysis before the experiment showed that the soil has low soil $\mathrm{pH}$ (5.11), high Fe and Mn. Tan (1992) stated that the lower of $\mathrm{pH}$, so the greater the $\mathrm{Al}, \mathrm{Fe}$, and $\mathrm{Mn}$-soluble concentration, resulting in the greater amount of bound phosphorous. The growth variable only observed on the mother plant, since Indian pennyworth has a spreading growth because of the runner, so it does not represent the production, made the orthogonal test invalid, and this suggested a new set variables should be established on C. asiatica.

\section{Production Component}

Phosphorous fertilization insignificantly influenced fresh and dry weight of total harvest at 5 MAP. The total fresh weight ranged between 755.50-946.10 g $\mathrm{m}^{-2}$ and the total dry weight ranged between 128.40$173.32 \mathrm{~g} \mathrm{~m}^{-2}$. Phosphorous content of plant tissue was analyzed once at 5 MAP. Phosphorous fertilization insignificantly influenced the phosphorous content of plant tissue of Indian pennyworth. The average phosphorous content in plant tissue is presented in Table 3.

Table2. The growth components of Indian Pennyworth

\begin{tabular}{|c|c|c|c|c|c|}
\hline \multirow[t]{2}{*}{$\begin{array}{c}\mathrm{P}_{2} \mathrm{O}_{5} \text { fertilizer } \\
\left(\mathrm{kg} \cdot \mathrm{ha}^{-1}\right)\end{array}$} & \multirow{2}{*}{$\begin{array}{c}\text { Total Leaf } \\
\text { Number } \\
4 \text { WAP }\end{array}$} & \multirow{2}{*}{$\begin{array}{c}\begin{array}{c}\text { Leaf Length } \\
\text { (cm) }\end{array} \\
4 \text { WAP }\end{array}$} & \multicolumn{2}{|c|}{$\begin{array}{l}\text { Total Flower Number } \\
\quad \text { (flower.plant }^{-1} \text { ) }\end{array}$} & \multirow{2}{*}{$\begin{array}{c}\begin{array}{c}\text { Leaf } \\
\text { Thickness } \\
(\mathrm{mm})\end{array} \\
8 \mathrm{WAP}\end{array}$} \\
\hline & & & $6 \mathrm{WAP}$ & $16 \mathrm{WAP}$ & \\
\hline 0 & $5.2 \mathrm{~b}$ & $3.0 \mathrm{ab}$ & $1.0 \mathrm{a}$ & $4.2 \mathrm{a}$ & $0.3 \mathrm{ab}$ \\
\hline 30 & $6.4 \mathrm{a}$ & $3.2 \mathrm{ab}$ & $1.1 \mathrm{a}$ & $4.3 \mathrm{a}$ & $0.4 \mathrm{a}$ \\
\hline 60 & $4.7 \mathrm{~b}$ & $2.9 \mathrm{~b}$ & $0.4 \mathrm{~b}$ & $3.4 \mathrm{ab}$ & $0.3 \mathrm{c}$ \\
\hline 90 & $4.8 \mathrm{~b}$ & $2.9 \mathrm{~b}$ & $0.7 \mathrm{ab}$ & $2.9 \mathrm{~b}$ & $0.3 \mathrm{bc}$ \\
\hline 120 & $5.6 \mathrm{ab}$ & $3.2 \mathrm{a}$ & $1.0 \mathrm{ab}$ & $4.6 \mathrm{a}$ & $0.3 \mathrm{abc}$ \\
\hline F Test & $*$ & $*$ & $*$ & $*$ & $*$ \\
\hline
\end{tabular}

Note: Figures followed by different letters in the same row significantly different at 5\% DMRT test

**: very significant on the level of $1 \%$, *: significant on the level $5 \%$ 


\section{J. Hort. Indonesia 2(1):1-5. April 2011.}

Table3. The average of phosphorous content in plant tissue on 5 MAP

\begin{tabular}{cc}
\hline Dosage of $\mathrm{P}_{2} \mathrm{O}_{5}$ fertilizer $(\mathrm{kg} / \mathrm{ha})$ & Phosphorous Content in Plant Tissue \\
\hline 0 & 0.216 \\
30 & 0.272 \\
60 & 0.238 \\
90 & 0.242 \\
120 & 0.260 \\
F Test & Ns \\
\hline
\end{tabular}

Note: **: very significant on the level of $1 \%$, *: significant on the level 5\%, ns: not significant

Phosphorous fertilization significantly influenced crop production components at $6 \mathrm{MAP}$ (Table 4). The treatment of $60 \mathrm{~kg} \mathrm{P}_{2} \mathrm{O}_{5} \cdot$ ha $^{-1}$ increased the total and shoot fresh weight value (76.72 and $82.92 \%$, respectively) and total, shoot and leaf dry weight $(89.30,97.59$ and $63.18 \%$, respectively) compared to that without fertilization.

The moisture content of plot harvest 6 MAP ranged between 80.79-81.93\%. Sutardi (2008) reported that harvesting at $4 \mathrm{MAP}$ and $108 \mathrm{~kg} \mathrm{P}_{2} \mathrm{O}_{5}$ $\mathrm{ha}^{-1}$ fertilizer significantly increased wet and dry weight of Indian pennyworth, but the asiaticoside content was not significantly different.

The regression of phosphorous fertilization quadratically insignificantly influenced the total of dry weight, the dry shoot weight, dry leaf weight, with equation: $\mathrm{Y}=88.0160+1.768500 \mathrm{x}-0.0141658 \mathrm{x}^{2}$ $\left(R^{2}=0.201\right), Y=75.5620+1.67274 x-0.0134295 x^{2}\left(R^{2}\right.$ $=0.408), \quad Y=27.9023+0.411006 \mathrm{x}-0.0031215 \mathrm{x}^{2}$ $\left(\mathrm{R}^{2}=0.631\right)$, respectively. The optimum dosage of Indian pennyworth for the total of dry weight, dry shoot weight, dry leaf weight were $62.42,62.28$ and $65.84 \mathrm{~kg} \mathrm{P}_{2} \mathrm{O}_{5}$ ha $^{-1}$, respectively.

Indian pennyworth productivity in the treatment $60 \mathrm{~kg} \mathrm{P}_{2} \mathrm{O}_{5} \mathrm{ha}^{-1}$ reached 6.79 tons shoot wet weight.ha ${ }^{-1}, 1.34$ tons dry shoot weight $\mathrm{ha}^{-1}$, and $451.70 \mathrm{~kg}$ dry leaf $\mathrm{ha}^{-1}$. These results were lower than the previous research of Sutardi (2008) that reported the productivity of Indian pennyworth from $108 \mathrm{~kg} \mathrm{P}_{2} \mathrm{O}_{5}$ ha $^{-1}$ application for plot harvested at 4 MAP reached 6.94 tons shoot wet weight.ha ${ }^{-1}$ and 1.85 tons shoot dry weight ha ${ }^{-1}$. Sutardi (2008) used manure or organic fertilizer as base fertilizer but no inorganic fertilizer. The influence of phosphorous fertilization on the $6 \mathrm{MAP}$ production components is quadratic. The result of regression analysis on total, shoot weight, and leaves dry weight 6 MAP showed that the optimum dosage to increase the dry weight production of Indian pennyworth was $65.84 \mathrm{~kg} \mathrm{P}_{2} \mathrm{O}_{5}$ $\mathrm{ha}^{-1}$.

\section{CONCLUSIONS}

Phosphorous fertilization significantly increased the total leaf number of mother plant and leaf length at 4 WAP, the total flower number of mother plant at 6 and $16 \mathrm{WAP}$, and the leaf thickness at $8 \mathrm{WAP}$. The treatment of $30 \mathrm{~kg} \mathrm{P}_{2} \mathrm{O}_{5} \cdot \mathrm{ha}^{-1}$ gave higher total leaf number of mother plant than

Table 4. The average of production components on 6 MAP

\begin{tabular}{|c|c|c|c|c|c|c|}
\hline $\begin{array}{c}\mathrm{P}_{2} \mathrm{O}_{5} \\
\left(\mathrm{~kg} \mathrm{ha}^{-1}\right)\end{array}$ & $\begin{array}{c}\text { Total Wet } \\
\text { Weight } \\
*)\end{array}$ & $\begin{array}{c}\text { Total Dry } \\
\text { Weight } \\
*)\end{array}$ & $\begin{array}{c}\text { Shoot Wet } \\
\text { Weight }\end{array}$ & $\begin{array}{c}\text { shoot Dry } \\
\text { Weight }\end{array}$ & $\begin{array}{c}\text { Leaves Dry } \\
\text { Weight }\end{array}$ & $\begin{array}{c}\text { Roots Dry } \\
\text { Weight } \\
*)\end{array}$ \\
\hline & & & $\ldots . . . \mathrm{g} \mathrm{m}^{-2}$ & & & \\
\hline 0 & $427.40 \mathrm{~b}$ & $78.42 b$ & $371.20 \mathrm{~b}$ & $67.65 b$ & $27.68 \mathrm{c}$ & 10.77 \\
\hline 30 & $747.90 \mathrm{a}$ & $145.74 a$ & $657.10 \mathrm{a}$ & $127.46 a$ & $36.58 b$ & 18.28 \\
\hline 60 & $755.30 \mathrm{a}$ & $148.45 \mathrm{a}$ & $679.00 \mathrm{a}$ & $133.67 \mathrm{a}$ & $45.17 \mathrm{a}$ & 14.77 \\
\hline 90 & $596.20 \mathrm{ab}$ & $107.93 \mathrm{ab}$ & $531.90 \mathrm{ab}$ & $95.40 \mathrm{ab}$ & $35.32 b$ & 12.53 \\
\hline 120 & $590.70 \mathrm{ab}$ & $107.62 \mathrm{ab}$ & $515.70 \mathrm{ab}$ & $92.85 \mathrm{ab}$ & $33.78 b$ & 14.76 \\
\hline F Test & $*$ & $*$ & * & $*$ & $* *$ & ns \\
\hline
\end{tabular}

Note: Figures followed by different letters in the same row significantly different at 5\% DMRT test

**: very significant on the level of $1 \%$, *: significant on the level $5 \%$, ns: not significant, *): Transformation $(\mathrm{X}+$ $0.5)^{0.5}$ 
treatments. Phosphorous fertilization significantly increased total and shoot dry and fresh weight plot $^{-1}$, and leaf dry weight plot $^{-1}$ harvested at 6 MAP. The optimum dosage to increase the dry weight production of Indian pennyworth in high altitude is $65.84 \mathrm{~kg} \mathrm{P}_{2} \mathrm{O}_{5} \mathrm{ha}^{-1}$.

\section{ACKNOWLEDGEMENT}

The research was funded by The Agricultural Research Partnership with Higher Education, The National Agricultural research and Development, Ministry of Agriculture, Agency of Agriculture Research and Developmen (AARD).

\section{REFERENCES}

Agusta, A. 2006. Diversitas jalur biosintesis senyawa terpena pada makhluk hidup sebagai target obat antiinfektif (Diversity of the terpene biosynthetic pathways in living organisms as atiinfective drug targets). Berita Biologi 8(2):141-152.

Bermawie, N., S. Purwiyanti, Mardiana. 2006. Keragaan morfologi, hasil dan mutu plasma nutfah pegagan (Centella asiatica (L.) Urban). Bul. Penel. Tanaman Rempah dan Obat XIX (1):1-17.
Hardjowigeno, S. 2003. Ilmu Tanah. Akademika Pressindo. Jakarta. 286 p.

Januwati, M., M. Yusron. 2005. Budi daya tanaman pegagan.http//balittro.litbang.deptan. go.id. [22 Maret 2008].

Marschner, H. 1995. Mineral nutrition of higher plants. Academic Press Harcourt Brace Jovannovich Publ. London

Martono, B., M. Ghulamahdi, L.K. Darusman, S.A. Aziz, N. Bermawie. 2010. Kriteria penanda seleksi produktivitas terna dan asiatikosida pada pegagan (Centella asiatica (L.) Urban. Jurnal Penelitian Tanaman Industri (Industrial Crops Research Journal) 16(1):20-26.

Sutardi. 2008. Kajian waktu panen dan pemupukan fosfor terhadap pertumbuhan dan produksi asiatikosida tanaman pegagan (Centella asiatica L. Urban) di dataran tinggi. Tesis. Sekolah Pasca Sarjana. Institut Pertanian Bogor. Bogor. $82 \mathrm{p}$.

Tan, K. H. 1991. Dasar-Dasar Kimia Tanah. Translator Goenadi, D. H. Gadjah Mada University Press. Yogyakarta. 295 p. Translation from: Principles of Soil Chemistry.

Winarto, W.P., M. Surbakti. 2003. Khasiat dan Manfaat Pegagan, Tanaman Penambah Daya Ingat. Agromedia Pustaka. Jakarta. 64 p. 